The Cambridge Journal of Postcolonial Literary Inquiry, 7(1), pp 14-34 January 2020.

(c) Cambridge University Press, 2019 doi:10.1017/pli.2019.22

This is an Open Access article, distributed under the terms of the Creative Commons Attribution licence (http:// creativecommons.org/licenses/by/4.0/), which permits unrestricted re-use, distribution, and reproduction in any medium, provided the original work is properly cited.

\title{
Nostalgia for Otiose Leisure: Laying Claim to an Indian Tradition of Otium
}

Monika Fludernik

\begin{abstract}
Focusing on the representation of leisure or otium, the article discusses recent South Asian fiction and its idealization of states of otiose leisure that existed in the past and are now nostalgically dwelled on in contrast to current conditions of stress exacerbated by global capitalism. After explaining the origin of this approach to South Asian fiction in an interdisciplinary research cluster on otium, the main thesis of the article is laid out. An example text, Sunetra Gupta's A Sin of Colour, is used to illustrate the various aspects of nostalgic leisure. The article also discusses narrative strategies that enhance a readerly experience of retardation and concentration.
\end{abstract}

Keywords: leisure, nostalgia, Sunetra Gupta

In the context of an interdisciplinary project on otium at the University of Freiburg in Germany, ${ }^{1}$ I am directing a project on otium ("leisure") in contemporary Indian novels that focuses on texts from the north of India, concentrating on English-language fiction in comparison with the Urdu and Bangla tradition. The research took its starting point from the realization that there exists a substantial number of English-language novels that idealize moments and practices of leisure, which, they lament, have sadly disappeared from contemporary life. In some texts, this nostalgia for former experiences of otium is contrasted with contemporary social and labor conditions in South Asia, in

Monika Fludernik is a professor of English literature at the University of Freiburg in Germany. She is also the director of the graduate school Factual and Fictional Narration (GRK 1767). Her major fields of interest include narratology, postcolonial studies, "Law and Literature" and eighteenth-century aesthetics. She is the author of The Fictions of Language and the Languages of Fiction (1993), the award-winning Towards a "Natural" Narratology (1996), Echoes and Mirrorings: Gabriel Josipovici's Creative Oeuvre (2000), An Introduction to Narratology (2009), and Metaphors of Confinement: The Prison in Fact, Fiction and Fantasy (2019). Among her several (co)edited volumes are Hybridity and Postcolonialism: Twentieth-Century Indian Literature (1998), Diaspora and Multiculturalism: Common Traditions and New Developments (2003), In the Grip of the Law: Prisons, Trials and the Space Between (2004), Beyond Cognitive Metaphor Theory: Perspectives on Literary Metaphor (2011), and Idleness, Indolence and Leisure in English Literature (2015). (Email: sekretariat.fludernik@anglistik.uni-freiburg.de)

1 SFB (Sonderforschungsbereich) stands for a format funded by the German Research Foundation (DFG), called a Collaborative Research Centre in the official English translation. See https://www.sfb1015.unifreiburg.de/en?set_language=en. Funding for the project is gratefully acknowledged. 
which the Western work ethic seems to rule supreme. Early post-Independence examples of the otium motif link the perceived lack of leisure to colonialism and to imposed British habits of industry, thus adding a clear framework of (post)coloniality to the topic. The main thesis of the project is that the idealization of indigenous Indian leisure should be interpreted as a reaction to globalization and its effects on the Indian (upper) middle classes. From that perspective, the nostalgia depicted in contemporary novels turns out to concentrate less on former opportunities for leisure among Indians but emerges as a sentimental yearning for the recuperation of a lost way of life that may be linked to class privilege or even to the entitlements and prerogatives of the Indian upper classes under the raj. The longing for the glories of erstwhile leisure can therefore be characterized as a feature that shares significant elements with recent theoretical concepts such as autoexoticism or re-Orientalism. ${ }^{2}$

The article falls into four parts. I will illustrate the motif of lost indigenous leisure in a series of key passages from a variety of texts, starting with a definition of what is here referred to as otium, leisure, or more properly, otiose leisure (sections 1 and 2). In a second move, I will turn to one text that I will analyze at length, Sunetra Gupta's A Sin of Colour (1999; section 3). My final section will consider to what extent the analyzed phenomenon can be described as a productive strand in contemporary South Asian fiction.

\section{Leisure, Otium, Otiose Leisure}

The Collaborative Research Centre (CRC) SFB 1015 focuses on $M u ß e$, a German word that is roughly synonymous with the Latin otium (antonym of negotium "work") and associated with the Roman political elite's retreat to their country houses as documented in epistolary prose by, among others, Cicero or Sallust. Otium also invokes the Greek term $\sigma \chi 0 \lambda \eta$, which has a more definite association with philosophical enquiry, $\theta \varepsilon \omega \rho i \alpha .{ }^{3}$ The German word $M u ß e$, although no longer employed widely in its elitist sense of an artistic or literary style of life, is nevertheless currently used in contemporary German, especially in the phrase Zeit und Muße (literally: "time and leisure") referring to free time that may be spent on leisurely and mostly pleasurable activities. ${ }^{4} \mathrm{Mu} \beta e$ comprises a wide range of situations from relaxation and doing little or nothing all the way to more strenuous activities both physical and intellectual. The main characteristic of $\mathrm{Muße}$ lies in the experience of quality time well spent with decidedly positive connotations.

In other languages, this concept is difficult to reduce to one word. Thus, in English, the word leisure may in fact denote $M u ß e$, but only when it is opposed to other activities or states that are contrasted with leisure in a derogatory manner, mostly with idleness or

2 Xiaofan Amy Li, "Introduction: From the Exotic to the Autoexotic," PMLA 132.3 (2017): 392-96; Lisa Lau, "Re-Orientalism: The Perpetration and Development of Orientalism by Orientals," Modern Asian Studies 43.2 (2009): 571-90; Lisa Lau and Om Prakash Dwivedi, Re-Orientalism and Indian Writing in English (Basingstoke: Palgrave Macmillan, 2014).

3 On the meanings of otium and the Greek terminology see the first two volumes of the Otium series: Franziska C. Eickhoff, ed. Muße und Rekursivität in der antiken Briefliteratur, Otium 1 (Tübingen: Mohr Siebeck, 2016); Günter Figal, Hans W. Hubert, and Thomas Klinkert, eds., Die Raumzeitlichkeit der Muße, Otium 2 (Tübingen: Mohr Siebeck, 2016).

4 A COSMAS database research on the use of $M u ß e$ in a collection of contemporary German newspapers showed that the phrase Zeit und $M u ß e$ occurred as by far the most frequent collocation. Results were presented in a colloquium on digital humanities in November 2017 and remain as yet unpublished. 
laziness. However, leisure in English more frequently denotes simply "free time," that is, time in which one does not have to work (equivalent to German Freizeit), and it nowadays includes many activities from travel and tourism to sports, wellness, or stamp collecting, which often do not necessarily or inherently induce the experience of otium. In fact, in sociological theories of acceleration, ${ }^{5}$ our leisure is said to be so overloaded with activities, subject to planning and even to meeting benchmarks (to run for at least three miles a day, to achieve a good result in the tennis match, to climb a particular mountain, etc.) that it does not feel like otium $(\mathrm{Muße})$ at all, but in fact evolves into one more stress factor, thus exacerbating people's impression of a lack of time, a lack of real relaxation.

Another English word is idleness; although idleness was used in positive connotations in the eighteenth century and the early Romantic period ${ }^{6}$ and has been utilized by a number of authors criticizing the work ethic (for instance, Jerome K. Jerome in Idle Thoughts of an Idle Fellow, Bertrand Russell in In Praise of Idleness, Robert Louis Stevenson in "An Apology for Idlers," all the way to Tom Hodgkinson's more recent How To Be Idle), ${ }^{7}$ the present-day use of idle(ness) is almost exclusively derogatory and therefore unsuitable as an equivalent of $\mathrm{Muße}$ (see O'Connor's recent study). ${ }^{8}$ This is even truer of another romantic word that used to be positively connoted, namely indolence, which, from an original meaning of a lack of activity and a vegetable state of passivity, briefly became a code word for artistic creativity. ${ }^{9}$ Though repose, retreat, and relaxation can be used to denote $M u ß e$, this is not a regular translation option because, as already noted, otium may often involve activity. The problem of translation does not merely relate to the English language; it poses itself equally for French and Russian, to name just two other languages. ${ }^{10}$ (I will come back to Indian terms later.)

In the CRC, we have therefore proposed a formal description of $M u ß e$ that contains the following features. Otiose leisure is a specifically inflected mode of the use of free time (leisure time) that depends on the limitation of one's temporal freedom from ordinary constraints impacting on one's time management. Periods of $M u ß e$ are moments or segments of leisure that are bounded and therefore acquire an experimental quality of enhanced freedom, heightened enjoyment, and an intensification of ongoing mental activity. Thus, one's moments of true leisure are both determined by a freedom from

5 Hartmut Rosa, Fast Forward-Essays zu Zeit und Beschleunigung: Standpunkte junger Forschung (Hamburg: Edition Körber, 2005).

6 Monika Fludernik and Miriam Nandi, eds., Idleness, Indolence and Leisure in British Literature (Basingstoke: Palgrave, 2014); Monika Fludernik, "Spectators, Ramblers and Idlers: The Conflicted Nature of Indolence and the Eighteenth-Century Tradition of Idling," Anglistik 28.1 (2017): 133-54.

7 Tom Hodgkinson, How to Be Idle (London: Penguin, 2005); Jerome K. Jerome, The Idle Thoughts of an Idle Fellow (Leipzig: Tauchnitz, 1886); Bertrand Russell, In Praise of Idleness and Other Essays (London: Routledge, 2007); Robert Louis Stevenson, “An Apology for Idlers [1877]," in The Works of Robert Louis Stevenson, ed. Edmund Gosse, vol. 2 (London: Cassell, 1906), 353-63.

8 Brian O'Connor, Idleness. A Philosophical Essay (Princeton, NJ: Princeton University Press, 2018).

9 Richard Adelman, Idleness, Contemplation and the Aesthetic, 1750-1830 (Cambridge: Cambridge University Press, 2011).

10 Anna Karina Sennefelder, ed., Rückzugsorte des Erzählens: Muße als Modus autobiographischer Selbstreflexion, Otium VII (Tübingen: Mohr Siebeck, 2018); Anna Karina Sennefelder and Georg Feitscher, "Oisiveté," in Dictionnaire de la fatigue, ed. Philippe Zawieja (Genf: Librairie Droz, 2016), 605-16; Elisabeth Cheauré, ed., Muße-Diskurse: Russland im 18. und 19. Jahrhundert, Otium 4 (Tübingen: Mohr Siebeck, 2017). 
imposed constraints (e.g., deadlines, schedules, immediate tasks) and a freedom for a particular otium activity, or project. ${ }^{11}$ We can use our Muße time to meditate or to listen to music; to relax while hiking, dancing, or swimming; one can also engage in a burst of musical composition or in a work flow of concentrated reading or writing. The freedom from formula relates to the boundedness of our otium experience; it is the prerequisite of freedom for, that is, our ability to freely use this time to do something creative or to achieve a qualitatively different experience of time. It is common for people enjoying $\mathrm{Mu} \beta$ e to say that for them time seems to stand still or has slowed down. This experience of deceleration becomes possible only once one withdraws into a bounded space or temporal slot without interruptions or outside interference; such a retreat from immediate concerns allows one to shut out one's everyday routines and obligations.

The use of leisure time therefore closely resembles that of quality time in English parlance. A specific feature of otium concerns the fact that time is no longer mainly instrumentalized as a temporal resource for achieving a specific aim or objective-we may devote the evening to finishing our income tax returns, but that evening is hardly going to be experienced as leisure. As the recurring German phrase Zeit und Muße ("time and leisure"), for tasks that are perceived as inherently pleasurable, indicates, however, the fact of performing a task does not in itself necessarily render an experience of otium impossible. If you are sorting through your slides from last year's holidays, the time spent doing so is not necessarily focused on the completion of that task (you do not necessarily have to have sorted all ten films by $10 \mathrm{p} . \mathrm{m}$.), but on the happy memories of your trip.

This quality time characteristic of $M u ß e$ can also be described by means of a set of paradoxical formulations that delineate the peculiar experience of otium:

• "Tätige Untätigkeit” ("active passivity")

- "Produktive Unproduktivität" ("productive laziness")

- "Bestimmte Unbestimmtheit" ("contoured freedom" or "limitless limitation") ${ }^{12}$

These three paradoxes (or oxymora) characterize the conjunction of activity and inactivity, dolce far niente and productivity, as well as the experience of illimitable freedom within clear boundaries.

Having explained what the focus of our research into Muße (which I will keep referring to as otium, leisure, or otiose leisure), I turn to Indian literature and otium.

\section{From the Lazy Native to the Glorious Leisure Days of Yore}

When talking about leisure, idleness and otium in texts about and from India, one first needs to consider possible vernacular treatments of the topic and also examine

11 Jochen Gimmel and Tobias Keiling, Konzepte der Muße (Tübingen: Mohr Siebeck, 2016).

12 See Burkhard Hasebrink and Peter Philipp Riedl, eds., Muße im kulturellen Wandel. Semantisierungen, Ähnlichkeiten, Umbesetzungen, linguae \& litterae, 35 (Berlin: de Gruyter, 2014), 3; Burkhard Hasebrink and Thomas Klinkert, eds., Muße. Konzepte, Räume, Figuren: Der Freiburger Sonderforschungsbereich 1015 im Überblick (Freiburg: Albert-Ludwigs-Universität Freiburg, SFB 1015, 2014), 13, 36; Gimmel and Keiling, Konzepte der Muße; Gregor Dobler and Peter-Philipp Riedl, "Introduction," in Muße und Gesellschaft, eds. Dobler and Riedl, Otium 5 (Tübingen: Mohr Siebeck, 2017), 1-17, esp. 3. 
colonial views about these concepts. Only on that basis can one proceed to an analysis of post-Independence representations and thematizations of $\mathrm{Muße}$.

Native traditions. What one immediately associates with the topic in preIndependence India are the courts of the nawabs and rajas, that is, the indigenous rulers of India including the Mughal and Hindu courtly traditions. Courtiers were involved in extensive literary and artistic practices, among which music and dance as well as the delivery of poems and theatrical performances were common. Both the practice of the arts, for instance poetic composition or the performance of ragas, and the enjoyment of these arts on the part of the courtly audience can-given the suitable attitude-be associated with otium. It is to be noted that these kinds of leisure are primarily restricted to the social groups involved with the court; as is frequently the case when one observes the practices of otiose leisure, one is looking at elite cultures or privileged social groups that do not need to work for their subsistence. (Perhaps more information will become available in the wake of subaltern studies, which has so far not yet focused on leisure as a topic.) Because our research group does not include classical Indologists and concentrates on the contemporary South Asian novel, we do not have the competence or time to analyze pre-Independence traditions of otium in proper historical fashion; this would be a task for more than one subsequent research project.

Urban flânerie-arguably already a motif in the figures of the vita and nāgaraka of the Sanskrit dramatic genre called caturbhāni (fifth to sixth century CE $)^{13}$-plays a prominent role in some Anglophone novels (as in the work of Amit Chaudhuri), in contemporary Bangla literature, and in representations of life in Lahore. ${ }^{14}$ Besides flânerie, meditation and monastic retreat in traditional Indian culture are not necessarily experienced as "otiose"; on the contrary, the classical Indian tradition of yogis, sadhus, and $n \bar{a} g a$ are based on extensive practices of arduous (self-)discipline. ${ }^{15}$ In Western colonial stereotypes, these sädhus figure either as idle and repugnant icons of Indian superstition and monstrosity (the Orientalist viewpoint ${ }^{16}$ ) or as idols of a spiritual life that-to Western eyes-appears to be the epitome of Muße. This latter positive (but entirely mistaken) vision of Indian (Sufi, Buddhist, Jain) asceticism must therefore be identified with a latent Orientalism or exoticism based on a long tradition of cultural primitivism. ${ }^{17}$ Eighteenth-century ideas about the noble savage as they infiltrated

13 See S. K. De, "A Note on the Sanskrit Monologue-Play (Bhana), with Special Reference to the Cathurbani," Journal of Royal Asiatic Society 58.1 (1926): 63-90; Klara Gönc Moačanin, "Indian Society as Depicted in the Caturbhāṇi and the Mahendravikramavarman's Prahasanas," Cracow Indological Studies 14 (2012): 133-45.

14 See Anna Suvorova, Lahore: Topophilia of Space and Place (Oxford: Oxford University Press, 2011); and Farha Noor, Reading Leisure in South Asia through a Comparative Study of Bangla and Urdu Fiction, PhD thesis in progress, University of Freiburg/University of Heidelberg. A good example of a novel focusing on these topics is Sankar's (Mani Shankar Mukherjee's) novel Chowringhee from 1962, translated by Arunava Sinha (Delhi: Penguin India, 2007).

15 Axel Michaels, Die Kunst des einfachen Lebens: Eine Kulturgeschichte der Askese (Munich: Beck, 2004); but see Paul Heintzman, Leisure and Spirituality: Biblical, Historical and Contemporary Perspectives (Ada, MI: Baker Academic, 2015).

16 Compare Ronald Inden, Imagining India (Oxford: Blackwell, 1990).

17 On primitivism see Arthur O. Lovejoy and George Boas, Primitivism and Related Ideas in Antiquity ([1935]; reprint, Baltimore: The Johns Hopkins University Press, 1997). However, some traditions of Sufism (for instance, see the Sufi poet Amir Khusrau), Bhakti poetry, and the practices of wandering minstrels such 
romantic literature in works such as Jacques-Henri Bernardin de Saint-Pierre's La chaumière indienne (1790), Robert Bage's Hermsprong (1796), or François-René de Chateaubriand's Atala $(1801)^{18}$ played a crucial role in perpetuating clichés about "Eastern" spiritualism. In the twentieth century, Western fascination with Indian ashrams and with yoga continued this tradition, which ends up being roundly ridiculed in contemporary Indian literature. (See, for instance, Pankaj Mishra's The Romantics, 1999, or Manjula Padmanabhan's Getting There, 2000. ${ }^{19}$ )

Colonialism and its aftermath. Besides exoticist or latently Orientalist modes of perceiving Indian leisure, its representation in the colonial novel needs to be considered. In British novels about India and the British in India, otium prominently relates to depictions of the colonists' relaxing holidays and leisure activities. This practice of otiositas is inflected by two main factors: on the one hand, the (partially unconscious) mimicry of the leisure of South Asian rulers by British functionaries (thus, the whole discourse about the so-called nabob is typically linked to the scandal of the nouveauxriches), ${ }^{20}$ and, on the other hand, the elevated living standards experienced by the expatriate colonists who were able to afford a lifestyle beyond their social station at home. British colonial households employed large numbers of servants. The leisurely pace of life in South Asia and other colonial territories was moreover made necessary by the heat that ruled out excessive physical exertion. Colonial leisure experience was distinctly gendered. Women (memsahibs) found themselves with much time on their hands. Whereas men would congregate in the clubs and spend their free time playing cards, drinking, and hunting, women's leisure, unless spent in reading and handicraft, often threatened to turn into boredom and depression. It may be questioned how much of this leisure was properly otiose in the sense of quality time, especially because it provided a basic index of living standards, a habitual availability of time and relief from the need for exertion, which should be opposed to the temporary and confined nature of

as Lalan Fakir (as portrayed in Sunil Gangopadhyay's fictional biography) do have some affinity with leisure or otium. Thanks go to Farha Noor for this information.

18 Jacques-Henri Bernardin de St. Pierre, La chaumière indienne, et le café de Surate (London, 1792), ECCO Literature and Language. Accessed October 8, 2018. http://find.galegroup.com/ecco/infomark.do? \& source=gale\&prodId=ECCO\&uuserGroupNam $=$ freiburg\&tabID=T001\&docId=CW3317135847\&type= multipagm\&contentSet=ECCOArticles\&version=1.0\&docLevel=FASCIMILE; Robert Bage, Hermsprong; or, Man as He is Not (Peterborough, Canada: Broadview Press, 2002); François René Chateaubriand, Atala/René, trans. Irving Putter (Berkeley: University of California Press, 1980).

19 Pankaj Mishra, The Romantics ([1999]; reprint, New York: Anchor Books, 2000); Manjula Padmanabhan, Getting There (London: Picador, 2000).

20 The nabob is the adventurer returned from India who is depicted as having amassed a fortune but is incapable of proper gentlemanly comportment, using his wealth for immoral ends such as bribery and sexual coercion. On the nabob stock character see James M. Holzman, "The Nabobs in England: A Study of the Returned Anglo-Indian, 1760-1785" (unpublished doctoral dissertation, Columbia University, 1926); Renu Juneja, "The Native and the Nabob: Representations of the Indian Experience in Eighteenth-Century English Literature," The Journal of Commonwealth Literature 27 (1992), 183-98; Percival Spear, The Nabobs: A Study of the Social Life of the English in Eighteenth-Century India ([1932]; reprint, Delhi: Oxford University Press, 1998); Ahsan Habib Chowdhuri, "The Fabulous Nabob: Miscegenations of Empire and Vocation in Eighteenth-Century British Literature" (unpublished doctoral dissertation, Auburn University, 2006); Christina Smylitopoulos, "Rewritten and Reused: Imagining the Nabob through 'Upstart Iconography," Eighteenth-Century Life 32.2 (2008), 39-59; Julie Codell, "Vulgar India from Nabobs to Nationalism: Imperial Reversals and the Mediation of Art," Victorian Vulgarity: Taste in Verbal and Visual Culture, eds. Susan David Bernstein and Elsie B. Michie (London: Routledge, 2009), 223-39. 
$M u ß e$. It is also worth pointing out that the imitation of rajas' and nawabs' lifestyle did not extend to a mimicry of courtly literary and artistic practices-except for hunting, the European administrators would rarely participate in courtly activities, especially in the poetic traditions (requiring a knowledge of Persian), or appreciate dance performances (considered indecent in polite company).

Even more important for the colonial perspective was the attribution of idleness or laziness that the colonizers attached to the colonial Other. The stereotype of the idle native or lazy native ${ }^{21}$ is one that pervades colonial discourse. Although it can be observed in general that otium is often claimed as a right by the socially privileged and denied to the lower classes (as discourses about lazy apprentices and servants in England amply document), ${ }^{22}$ in the colonial context the privilege of class merges with that of ethnicity or race and with the power differential between colonizers and colonized. A typical instance of this can be observed in Fanny Parkes's ticking off of her nursemaid while admitting that indolence is only natural in the climate for herself and the native ladies, the local elite:

The idleness of the natives is excessive; for instance my ayah will dress me, after which she will go to her house, eat her dinner, and then returning, will sleep in one corner of my room on the floor for the whole day. The bearers also do nothing but eat and sleep, when they are not pulling the pankhās... I knew not before the oppressive power of the hot winds, and find myself as listless as any Indian lady is universally considered to be; I can now excuse what I before condemned as indolence and want of energy-so much for experience. (19 March, 1823) ${ }^{23}$

Given this Orientalist or colonial denigration of native leisure, particularly of the native working classes, it is at first extremely odd to find a motif of native otium opposed to Western hurry prevailing in contemporary Indian literature. Not only does this contrast invert the colonial stereotype of native laziness by claiming that leisure is in fact an indigenous tradition that needs to be preserved against the ravages of (Western) neoliberal capitalism and globalization; it moreover seems to suggest that the West is incapable of understanding otium. Let us look at the following extract from Nayantara Sahgal's A Time to Be Happy (1958). In this passage Govind's artistic and leisurely otium devoted to the pleasurable study of art and the peaceful enjoyment of tea in his garden is contrasted with his brother's "British" habit of spending his leisure time in strenuous sport. Harish seems to have absorbed the Western work ethic of continuous effort and activity:

Govind Narayan ran a loving hand over her [the bronze goddess]... . His voice held the vibrant note it had whenever he acquired a new and beautiful object for his house... "Is she not exquisite? It is relaxation just to look at her."

21 The classic study that introduced this term is Syed Hussein Alatas, The Myth of the Lazy Native: A Study of the Image of the Malays, Filipinos and Javanese from the 16th to the 20th Century and Its Function in the Ideology of Colonial Capitalism (London: Frank Cass \& Co, 1977).

22 Sarah Jordan, The Anxieties of Idleness: Idleness in Eighteenth-Century British Literature and Culture (Lewisburg, PA: Bucknell University Press, 2003).

23 Fanny Parkes, Begums, Thugs and White Mughals ([1850]; reprint, London: Eland Publishing, 2002), 19. All emphases in bold are mine. 
As he stood there, himself outlined against the sky, his hand encircling the goddess's waist, I thought how different he was from Harish, for whom relaxation meant a cigar and a glass of port or ... to fling himself about the tennis court in pursuit of physical fitness. There was little time or inclination in Harish's life to pause in wonder or admiration. ${ }^{24}$

The desirable state of otium idealized in Sahgal's novel links to a lack of activities, to the almost epiphanic relishing of the moment and to the appreciation of art:
The afternoon sun spilled liquid fire on the rubies as I turned them over in my hand. As usual in Govind Narayan's company, I felt all urgency fall away and calm steal through me. In his garden, time had a way of lingering, and nothing was of any significance except the sunlight on the gems I held and the stillness that was studded, gem-like, with a hundred muted sounds. We were no longer individuals, but a part of the subdued brilliance, and the creatures about us seemed to sense this. A squirrel emerging from the foliage nearby daintily skirted the grass at my feet. A gauze-winged dragonfly settled lightly on my wrist. We sat for some minutes in quiet accord, I forgetting I still held the necklace, and he leaning back in his chair, oblivious of everything but the glowing day. Then a servant came, soft-footed, across the lawn with a cup for my tea. ${ }^{25}$

As one can see, the words associated with otium are relaxation, wonder, admiration, quiet, calm, and stillness, and they are contrasted with urgency and exertion. In the second example passage, there is a clear linking of nature (though in a garden) and the refined aesthetic pleasures of Govind's relaxation. However, this peaceful state of enjoyment depends on Govind's financial liquidity and the household arrangements it permits-he can afford a servant who delivers the tea.

The contrast with a "Western" lack of leisure is particularly thematized in Amitav Ghosh's The Hungry Tide, Upamanyu Chatterjee's English, August, Pankaj Mishra's The Romantics, and practically all the novels by Amit Chaudhuri. ${ }^{26}$ Many Anglophone texts, however, underline the virtues and pleasures of idleness more than they do the contrast between East and West or the tensions between capitalism and resistance to it; these oppositions are often merely implicit in the celebratory delineation of leisure time. Because South Asian fiction, even in English, increasingly concentrates on everyday life among South Asians at home or in the diaspora, theories of postcolonialism and the colonial/postcolonial dichotomy tend to become less and less relevant to the interpretation of these texts. By contrast, what emerges as particularly striking is the fact that frequently the enemy of leisure cannot be directly identified as the West in the figure of the former colonial power, but in relation to the work ethic of a globalized capitalism that is now present in India in a variety of shapes.

24 Nayantara Sahgal, A Time to Be Happy (New York: Knopf, 1958), I, ii, 21. My emphasis.

25 Sahgal, A Time to Be Happy, I, vi, 64. My emphasis.

26 Amitav Ghosh, The Hungry Tide ([2004]; reprint, London: HarperCollins, 2005); Upamanyu Chatterjee, English, August: An Indian Story ([1988]; reprint, Calcutta: Rupa \& Co, 1995); Mishra, The Romantics. For further texts that are central to the project see https://www.anglistik.uni-freiburg.de/department/deptadmin-sections/literary-studies/fludernik_chair/current-projects/musse-im-indischen-gegenwartsroman. 
In this context, globalization, ${ }^{27}$ in similarity to the United States or Germany, is primarily perceived as an economic system for the maximization of profits on the basis of worldwide financial and production-related outsourcing that tends to result in the loss of jobs with social security in the industrial nations and an increasing imposition of "Western" productivity standards in the global south. The effects of globalization are thus a Westernization of the workplace in the former colonies with regard to both the pace of work and the quality standards of products, and they entail a complementary "substandardization" of job security and social networks in the societies of the former colonial powers.

A good example case of the nostalgic depiction of otium under conditions of globalization in a prominent Anglophone novel is Upamanyu Chatterjee's English, August (1988). In this text, the protagonist's, Agastya's, indolence and refusal to work are not only reminiscent of Fanny Parkes's attitudes (Agastya's excuse is the heat), but he adopts a particularly "Western" attitude in pretending that his mother is English and in lying that he studied at Cambridge. He thus arrogates to himself an elite status. The work he is resisting against is of two kinds: bureaucracy and managerialism. On the one hand, there is the Indian Civil Service, which is described as a depressingly bureaucratic institution in which almost nothing seems to be accomplished despite an enormous waste of time on paperwork and meetings. Agastya's supercilious criticism of his colleagues is due to his upper-class assumption of superiority; his boss Srivastav, who had to work his way up the administrative ladder, is not bored and seems to be proud of his career. ${ }^{28}$ The second type of occupation for which Agastya expresses scorn is that of the city work that his friends engage in in banks, insurance companies, or offices of important international enterprises. His distaste for their obligation to wear suits and sit in offices all day is equally strong. The novel therefore presents two different versions of work abominated by Agastya that are linked to Western capitalism and globalization in one case and to the remnants of the colonial civil service adopted by India after Independence in the other. Agastya's practices of subversively undermining the ICS system in which he finds himself imprisoned consist in the refusal to adopt the furniture of his rooms; his late arrival in office, extensions of his lunch breaks, and slipping off from meetings; the refunctionalizing of official business trips as pleasure excursions; and his persistent refusal to learn the local language. His times of leisure (or should one say: lethargy?) are spent in his bed and listening to music.

How "Indian" is the leisure that the flâneurs and lazybones peopling the various otium texts indulge in? Although the scenarios of leisure (gardens, landscape, nature, beds, homes, etc.) and the stock characters of otium (the flâneur, the tourist, the hiker,

27 Although there are different definitions of globalization, they agree in considering "the economic integration of different countries through growing freedom of movement across national boundaries of goods, services, capital and people" as central (OECD, Fixing Globalization: Time to Make It Work for All, Better Policies Series, April 2017. https://www.oecd.org/about/sge/fixing-globalisation-time-to-make-itwork-for-all-9789264275096-en.htm. Though one can consider the ancient trade on the Silk Road or the intensive commercial exchange in the Mediterranean and between Europe and the colonies during the colonial period as instances of globalization, what is new is that the pace and extent of globalization has increased exponentially in the wake of digital technology. See also Gerold Ambrosius, Globalisierung: Geschichte der internationalen Wirtschaftsbeziehungen (Wiesbaden: Springer Gabler, 2018).

28 Chatterjee, English, August, 60. 
the writer, etc.) correspond to the types of leisure that the Freiburg CRC has been analyzing for French, Russian, or German literature, the specifically Indian or "traditional" quality of the practices described in the novels emerges particularly in relation to music, to social intercourse (especially, conversation), and to leisurely locomotion (strolling). South Asian musical traditions, notably the raga and the ghazal, play an important role in the novels of Amit Chaudhuri, Sunetra Gupta, and even Upamanyu Chatterjee. In European otium novels, ${ }^{29}$ art, whether poetry, music, dance, or painting, but also intellectual discussion, likewise figure pervasively. In the South Asian otium novels, these arts are in the majority native ones, even if the protagonists are also influenced by Western artistic or intellectual traditions. Curiously, a practice of otium that figures prominently in European and North American otium texts, namely that of writing (composing written texts, literature, or philosophy) is signally absent from the South Asian material that we have looked at, where instead reading (also a common activity in English, French, or Russian novels) and studying predominate, as in Pankaj Mishra's The Romantics. Leisure practices moreover display an important overlap with what Dipesh Chakrabarty has discussed under the heading of adda $(\bar{a} d d \bar{a})$, namely conversation and socializing (see more on this below); interestingly, adda is thematized more generally in nonfictional texts such as biographies, autobiographies, and literary essays. ${ }^{30}$

Nostalgia. The representation of otium in the contemporary South Asian novel in English is frequently imbued with nostalgia. As has been pointed out by Bernd-Peter Lange, Rabindranath Tagore is a recurrent reference point in contemporary diaspora novels, as also in our otium texts, especially in the works of Gupta and Chaudhuri. ${ }^{31}$ In the diasporic South Asian novel in English, Tagore as a cultural icon serves to invoke the importance of Bengali art and culture from the time of Rammohan Roy (1772-1833) onward. Nostalgia for the Bengali Renaissance emerges very strongly already in Sunil Gangopadhyay's Those Days (1985). This historical novel focuses on the "invention" of Bangla as a literary language, but it also showcases the Hindu entrepreneurial and professional classes, their wealth and their traditional attitudes-a traditionalism that the reformers in the novel are trying to break up. ${ }^{32}$ Although Those Days does not idealize colonial Calcutta (there is clear criticism of the prevailing discrimination of women and the lower classes), the choice of topic is nostalgic when viewed from the perspective of the novel's time of composition. This nostalgia can be linked both to the

29 Thomas Klinkert, Muße und Erzählen: Ein poetologischer Zusammenhang, Studium zur Theorie und Kulturgeschichte der Muße, Otium III (Tübingen: Mohr Siebeck, 2016).

30 Dipesh Chakrabarty, “Adda: A History of Sociality," Provincializing Europe: Postcolonial Thought and Historical Difference [originally published in 2000] (Princeton: Princeton University Press, 2008), 180-213. 31 Bernd-Peter Lange, “Tagore in the Diaspora: Presence, Ritual, Nostalgia," ZAA: Zeitschrift für Anglistik und Amerikanistik 63.4 (2015): 357-71. On nostalgia and longing in general, there is a vast amount of literature. To mention just two key works: see David Lowenthal, The Past Is a Foreign Country (Cambridge: Cambridge University Press, 1985) and Susan Stewart, On Longing. Narratives of the Miniature, the Gigantic, the Souvenir, the Collection (Durham, NC: Duke University Press, 1993). British nostalgia for the Raj and the Victorian period has of course been a staple of literary criticism, especially in connection with heritage movies.

32 Sunil Gangopadhyay, Those Days: A Novel, trans. Aruna Chakravarti ([1982]; reprint, Gurgaon: Penguin, 1997). 
financial depression affecting Bengal (which makes the glorious times of yore seem more attractive than they actually were) and to the envy elicited by the kind of lifestyle available to the protagonists in that period.

Nostalgia can be considered an inherent motif or sometimes an underlying raisond'être of the otium scenarios in the work we have analyzed in the CRC project. It is worth noting that nostalgia - in the meaning of a longing for the past and for social and cultural contexts that seem to be irrecuperable-is not a new phenomenon in South Asian writing. Hans Harder has drawn our attention to Tagore's indulgence in a nostalgic vision of his childhood and in the complexities of Tagore's hybrid allegiances. ${ }^{33}$ Even earlier, Urdu fiction in the nineteenth century dwelled with nostalgic passion on the lost world of Mughal glory, though this nostalgia was also ironized and even denounced. ${ }^{34}$ In the novels that we have been studying, there is not only a wistful treatment of Tagore, but generally an indulgence in reminiscences of unhampered freedom from schedules that might limit one's freedom. It is therefore quite logical that the experience of childhood figures so prominently in many of the otium texts, as it does in Chaudhuri's A Strange and Sublime Address (1991) ${ }^{35}$ and Afternoon Raag (1993), ${ }^{36}$ Ardashir Vakil's Beach Boy (1997), ${ }^{37}$ Raj Kamal Jha's The Blue Bedspread (1999), ${ }^{38}$ or Chaudhuri's Friend of My Youth (2017). ${ }^{39}$

I will now turn to my example text, which focuses on nostalgia and, tellingly, opens with a fantasy of the loss of influence and wealth.

\section{A Sin of Colour: Otium and Nostalgia}

Let us look at one example of nostalgia in recent diasporic English fiction, Sunetra Gupta's A Sin of Colour (1999). ${ }^{40}$ This novel, which is perhaps Gupta's most accessible book, focuses on the life of Deben(dranath) Roy-somewhat an alter ego of Tagore ${ }^{41}$ who is in love with his sister-in-law, Reba, and escapes to Oxford to study. There he comes to room with an elderly lady (called Aunt Mabel) whose niece, Jennifer, he ends up marrying. When they return to Calcutta to visit his parents, his love for Reba erupts again. He has a falling-out with his father and returns to Oxford. Unable to stomach his

33 Hans Harder, "Nostalgia and Autobiographies: Reading Rabindranath Tagore's Jibansmriti (1912) and Chhelebela (1937)," in HerStory-Historical Scholarship Between South Asia and Europe: Festschrift in Honour of Gita Dharampal-Frick, eds. Manju Ludwig and Rafael Klöber (Heidelberg: CrossAsia-eBooks, 2017), 190-209.

34 Farha Noor, Reading Leisure in South Asia through a Comparative Study of Bangla and Urdu Fiction. See also Margrit Pernau, "Nostalgia. Tears of Blood for a Lost World," South Asia Graduate Research Journal (SAGAR) 23 (2015): 75-109.

35 Amit Chaudhuri, A Strange and Sublime Address ([1991]; reprint, London: Minerva, 1994).

36 Amit Chaudhuri, Afternoon Raag ([1993]; reprint, New Delhi: Penguin Books India, 2012).

37 Ardashir Vakil, Beach Boy ([1997]; reprint, London: Penguin, 1998).

38 Raj Kamal Jha, The Blue Bedspread ([1999], reprint, London: Picador, 2000).

39 Amit Chaudhuri, Friend of My Youth (London: faber \& faber, 2017).

40 Sunetra Gupta, A Sin of Colour ([1999]; reprint, London: Phoenix, 2000).

41 Debendranath was the first name of Tagore's father; apparently, he also fell in love with and had a great affection for his sister-in-law, Kadambari Devi (married to Jyotirindranath Tagore in 1868, when she was ten years old and almost the same age as Rabindranath). She committed suicide in 1884, which was shortly after Rabindranath's marriage; see Anasua Basu Raychaudhury, "Nostalgia of 'Desh,' Memories of Partition," Economic and Political Weekly, 39.52 (2004): 5653-60. 
marriage, he fakes a punting accident on the river after having met his friend Daniel Faraday.

Years later, his niece Niharika, Reba's daughter, arrives in Oxford to study and rooms with her aunt, Jennifer. She falls in love with Daniel, who is married, and their affair ends in New York, where Daniel's friend Morgan consoles her. Morgan eventually commits suicide. Niharika returns to Oxford, finishes her $\mathrm{PhD}$, and goes to Calcutta, where she lives in the old family mansion and starts to write a novel about her uncle Deben with a plot in which he has faked his death.

Debendranath, who has lived the life of a simple artisan in the Himalayas, suddenly shows up in Calcutta when he is losing his eyesight. At the same time, Niharika starts to feel attracted to a doctor named Rahul. Deben is collected by his wife in Calcutta and taken back to Oxford. Niharika returns to Oxford to think about her future, intending to set her love for Daniel at rest and marry Rahul, when Daniel reappears and they go out boating and disappear. The strong suggestion is that they, too, have faked their deaths. On that day, Deben is able to look at the trinket that Morgan cherished and left to Niharika, the last beautiful thing Deben will be able to see before he goes completely blind.

The novel features extensive scenarios of otium and is also steeped in nostalgia. The very opening of the text depicts Deben's fantasy about his family's slide into poverty while he is away in England. This fantasy, which invokes his family's life of wealthy leisure (now lost), camouflages his real nostalgia, his unrequited and unspoken love for Reba. It serves to articulate his feeling of guilt for having left his family, for having exiled himself abroad to escape from his obsession with the unattainable love object, his sisterin-law; but it can also be linked to Bengalis' recurrent nostalgia for "Desh" in the wake of the partition of Bengal in 1947 and $1971 .^{42}$

It was not far from the railway station to the boarding house and he was able to drag his trunk across the road and down the narrow street by halting every few steps to blow upon his frozen fingers, and allow himself to be briefly immersed in the perverse fantasy that he might never see her again. Perhaps his family would fall upon hard times and he would never be able to afford his passage home, spend the rest of his life slaving as a schoolmaster in some obscure corner of Britain, while she, his brother's wife, started giving private tuition in Music and English to make ends meet. Their grand home in Calcutta would have to be auctioned, and the heavy furniture crammed like a herd of tired elephants into a small flat. His father might have to share a room with his grandchildren, give up his expensive habits, resign from his clubs, spend lonely hours on a narrow balcony staring out onto the street while the children did their homework and their mother perspired over a small kerosene stove as she prepared their evening meal. ${ }^{43}$

The conjunction of frustrated love for Reba whom Deben thinks about as giving music lessons-is he punishing her in his fantasy for not having reciprocated his incestuous love? - and his own obligation to work as a teacher evokes a feeling of self-pity that puts Deben's feelings and situation first before he arrives at the realization of what such poverty might mean for his father, only to return to Reba sweating over a kerosene stove.

42 See Raychaudhury, "Nostalgia of 'Desh,' Memories of Partition."

43 Gupta, A Sin of Colour, 3. Further references to this edition are given after quotations in the text. 
That latter vision is immediately contrasted with Reba's very luxurious kitchen utensils as he remembers them. ${ }^{44}$

Nostalgia, secondly, emerges in the memories of Deben's childhood home in Calcutta, which is, tellingly, called Mandalay. The more important scene of nostalgia is a cultural one that deals with Deben's fascination for his sister-in-law's father, a scholar who gathers his students about him and represents the epitome of traditional learning and native civilization: "His own family seemed hopelessly uncultivated by contrast." 45 Deben discovers "huge gaps in his knowledge of politics and history." 46 and starts to educate himself by browsing in bookshops. He frequents the house of Reba's family, enjoying

[t]hose wonderful evenings at Reba's father's house, when he would sit enthralled but tongueless in the winds of a fierce and splendid debate, and wish that he had at least a few choice words to offer, especially if, as was often so, she was there, at her father's feet, quietly voicing her own opinions, that he ached to endorse with an especially coruscating comment. $^{47}$

Comically, Deben's father Indranath feels he has lost his son to "the old professor in his dusty flat" ${ }^{\text {" }}$ who will "tutor him in all sorts of political blasphemy, turn his mind with poetry and sad rainsong." ${ }^{49}$ The word "rainsong" is significant because we have just learned that Reba's "smiles would fall into him [Deben] like rain falling after drought into the cupped palms of an aceramic race." ${ }^{50}$ The phrase moreover links to the extensive water imagery in the novel.

That feeling of displacement in view of Reba's cultured family-so different from his own very commercial background-also makes Deben realize that Reba is engulfed by a "sublime expanse of loneliness" ${ }^{11}$ in her new home so that she, too, in Deben's imaginings, must be racked by nostalgia for her own home:

He saw her as she sat upon the rush mat, her thick hair fanned out over her back, her fingers running soundlessly along the strings of her father's tanpura, and realized suddenly how lonely she must feel within the walls of his home, how sad the prospect of returning to her husband's home where she was so respected and valued, so adored. He saw her staring out through the window at the steel noon sky, and felt there was nothing so beautiful as her loneliness. $^{52}$

44 Gupta, $A$ Sin of Colour, 3.

45 Gupta, A Sin of Colour, 39.

46 Gupta, A Sin of Colour, 39.

47 Gupta, A Sin of Colour, 129.

48 Gupta, A Sin of Colour, 41.

49 Gupta, A Sin of Colour, 41.

50 Gupta, A Sin of Colour, 41.

51 Gupta, A Sin of Colour, 19.

52 Gupta, A Sin of Colour, 18. 
Reba's whole being is taken up with traditional music, with her playing the esraj, as in the scene when he comes to say good-bye to her after he ends the visit to Calcutta. ${ }^{53}$ Like her father, Reba seems to live in the past (of music) and concentrates on her art to the detriment of her daughter Niharika, who feels displaced in her affections by her mother's career. While her father mentions English words only in inverted commas, ${ }^{54}$ Reba steeps herself in the native musical traditions. Even the debates in her father's house strike Deben as "the rehearsal of a dedicated group of performing artists. ${ }^{n 55}$ Deben muses about her father's consent to the marriage, which seems to have been suggested by the family's uncertain financial situation, ${ }^{56}$ a point that returns us to the opening paragraph and implies that Deben, immersed in his thoughts about Reba, has been projecting her family's situation onto that of his own. Deben's love for Reba is also cast in musical metaphor and characterizes his love as nostalgia: "it had been clear to both of them that this was no longer just a haunting melody, but the abiding rhythm of his life." ${ }^{37}$

Nostalgia and leisure seem to mutually depend one on the other in the novel. It is only by having the time to muse about his obsession with Reba that Deben can immerse himself in nostalgic longing; at the same time, the scenarios he revisits in memory are scenes of cultured leisure, of music and intellectual exchange. Reba's music sessions are likewise an expression of her longing for her childhood and for her family, and these nostalgic memories are moreover imbued with the nostalgia for an irrecoverable past of Bengali cultural predominance.

Yet these scenarios of nostalgic sentiment in the novel are also being deliberately undercut by irony. There is, first, the location in one of the hill stations, where Deben spends time repairing broken china (while he is trying to cure his broken heart). The Himalaya scenes are not associated with a nostalgia for colonial vacationing; Deben's eavesdropping on family members tends to convey a satiric perspective on the elite's summer holidays in the mountains, even though his sojourn corresponds to an ideal life of otium (see below). The second failed nostalgic scenario is Mandalay, the family home. Having believed he could arrive back and insert himself into his former life of indolent meditation, Deben soon has to acknowledge that his story of deceitfully faking his death has become common knowledge and that he is eliciting curiosity and criticism for his behavior among the neighbors whenever he leaves the house.

As regards the central theme of otium in the text, let me note that all the major characters are intellectuals and artists and that they engage in artistic performance, composition, and in the contemplation of beauty: thus, Reba's musical performances and exacting routines of practicing her instrument. There are also Deben's intellectual and artistic interests, his talent for repairing broken china, and his contemplation of the locket that Morgan has left to Niharika, a lyre made from a curl of Keats's hair, whose "ethereal beauty," Deben knows, is perhaps "the last thing he will ever see." ${ }^{58}$ Deben's

58 Gupta, A Sin of Colour, 217. 
appreciation of art is the delight of Jennifer, who thinks back on how at an exhibition he would "step ... back from a painting or a collage with that strange look of intense concentration on his face, and she would hold her breath as he performed his assessment ... "59 And then there is Morgan, who is extremely rich and collects beautiful objects, including perhaps beautiful women like Niharika.

These artistic contemplative experiences are complemented by passages in which nature serves to enhance the emotional charge of the situation:

They [Debendranath Roy and his wife Jennifer] sat in the cold darkness in an almost empty hall, for it was not a time when it was likely to be crowded, and then the heavens opened above them, and they were lost in the massive movements of the stars and the comets and the rush of the galaxies, spinning away into infinity. He held her [Niharika's] small hand as she sat transfixed, engulfed within the stretches of dark velvet time, unfolding like a liquid within another lighter liquid before her eyes, and he found his mind was spinning with the ecstasy of her perception of the universe, and he knew he had not been so happy in a very long time, not since he had stumbled upon her mother [Reba] singing in the afternoon stillness, just a few weeks after she [Niharika] was born, singing of the devotee who knew not how to adore the Lord Buddha except through dance... . ${ }^{60}$ (my emphases)

The passage has some affinities with modernist epiphanies; its quality of transcendence is characterized by a great calm that Deben experiences and which he links to his initial sliding into desire for Reba. The extract illustrates another striking feature in otium texts, namely their stylistic, especially syntactic, predilection for slowing down one's reading pace through the use of long and complex sentences, utilizing a multitude of attributes and especially predicative enchainments. In the passage just quoted, one can observe several present participles ("spinning," "unfolding," "spinning," "singing"—printed in bold) as well as past participles in adjectival modifier function ("crowded," "transfixed," engulfed"-printed in italics). The paratactic series of clauses linked by and are complemented by a for-clause and the postmodificatory not since and just a few weeks after clauses that extend the main clause in a seemingly illimitable manner (in underline above). These syntactic strategies are apt to significantly slow down the reader's comprehension, and they induce in the audience an appreciation of the depiction of a gradual and halting cognitive process and of the author's nuanced verbal experimentation.

Niharika's love for Daniel, too, is connected to the contemplation of nature. She sits and looks at Tintern Abbey in the company of Daniel; their meditative leisure begins to transform itself into love:

She remembered her first sight of the Abbey, the drama of its sudden appearance against the mellow slopes of the Wye Valley, it had filled her with a great and amorphous hope. They had sat for hours in its eastern shadow, simply talking, and it had become clear to her then that her pleasure in his company was not simply that of a young woman relishing the attentions of a more mature and deeply fascinating man, that it was not just the tenuous

59 Gupta, A Sin of Colour, 56.

60 Gupta, A Sin of Colour, 55. 
mystery of her uncle's disappearance that connected them, but something much more subtle. $^{61}$

It is in keeping with the recurrent musical metaphors of the novel that Niharika's burgeoning moment of aesthetic affinity and love is described as "the music of that afternoon" and her memory of it as "run[ning] along the riverbed of her thoughts for a long time, until eventually it would sink leaving a fine trace of gold dust where it had run for so long." ${ }^{\prime 2}$ The idyllic location of this scene in a Western (British) location associated with the romantics is significant, and so is the fact that this exemplar of Britishness is a ruin (glories of the irrecoverable past). Oxford, too, functions as a site of leisure and Occidentalist nostalgia in the book.

The fact that Tintern Abbey is a building that has been destroyed moreover crossreferences another passage about South Asian nostalgia and romanticism in the book. During her time in Calcutta, Niharika accompanies Rahul to a village and goes sightseeing to the "ruins of a nameless house," ${ }^{33}$ musing about the family who has abandoned this "ancestral home" ${ }^{64}$ like "her family," who had had to escape from East Bengal ("the region of rivers, now part of a different country" ${ }^{\text {"65 }}$ ), and remembers her father's "nostalgia" ${ }^{66}$ for their old home. The passage also mentions Deben's blissful childhood, "frolick[ing] among the fisher folk" in "that magical land of rivers." ${ }^{67}$ Here, the nostalgia is not Occidentalist but entirely homegrown.

The noted strands of nostalgia and the experience of otium underline the parallel between Deben's and Niharika's type of illicit and distanced love tinged with unrequited desire and memories of imagined passion. One could even argue that the earlier passage, where Jennifer and Deben sit beside the sick Niharika, and Deben is reminded of his love for Reba by the spectacle of the stars and the presence of his niece, ${ }^{68}$ is in fact echoed by the scene in which Niharika takes care of her sick niece with Rahul in attendance and with Daniel not far from her thoughts. ${ }^{69}$

In A Sin of Colour, otium and nostalgia combine to cover up pain and illicit desire. Niharika wrongly sees her uncle's life in Oxford as a peacefully calm one, an "easy life, with its long vacations during which he had traveled extensively in Europe as had been his childhood dream." ${ }^{70}$ In reality, Deben's existence in Oxford is the opposite of idyllic because he tries to deaden himself to his nostalgia for home, which is centrally linked to his family's life of leisure and his fascination with Reba. At the same time, Niharika's vision of Oxford as a site of contemplation, research, and intellectual thrill idealizes the place and serves as a cover-up for her own affair with Daniel: Oxford (in which, actually, she was not all that happy) thus acquires an aura of quite unrealistic wistfulness and

61 Gupta, A Sin of Colour, 81.

62 Gupta, A Sin of Colour, 82.

63 Gupta, $A$ Sin of Colour, 74.

64 Gupta, A Sin of Colour, 175.

65 Gupta, A Sin of Colour, 175.

66 Gupta, A Sin of Colour, 175.

67 Gupta, A Sin of Colour, 175.

68 Gupta, A Sin of Colour, 55.

69 Gupta, A Sin of Colour, 148, 154-55.

70 Gupta, A Sin of Colour, 109. 
dreaming. Morgan, in his turn, claims to "like to do nothing, and plan to do nothing for the rest of [his] life." ${ }^{71}$ It is surely significant that Morgan's one treasure, the "locket with a lyre in it made from the hairs of Keats' head,"72 "enrapture[s]"73 Niharika completely, and that this object of Morgan's contemplative leisure reappears as Deben's final visual image, which (as the text suggests) he will revisit in his mind once complete darkness has set in, thus generating an incipient nostalgia for visions of beauty of which he will be deprived forthwith. ${ }^{74}$

\section{Leisure Discourse in Its Wider Context}

In my reading of Gupta's A Sin of Colour, I have concentrated on the link between leisure and nostalgia. In the Anglophone texts analyzed in our project, leisure appears both on the level of the setting of stories - characters are depicted as enjoying moments of leisure-and in the protagonists' desire for leisure, which they perceive to be lacking and long for. In either constellation, nostalgia may come to be foregrounded, and the subjective feeling of the characters is deployed to imply a nostalgic worldview for the novel as a whole, just as the narrative representation of leisure can project an idyllic counterfactual ideal. I have also noted that the language itself may syntactically and stylistically enhance the reader's experience of deceleration in the reading process. This is the case not only in Gupta's work but, even more extensively, in Chaudhuri's writing (much as, for some readers, this strategy has resulted in aversion). ${ }^{75}$ In Chatterjee's English, August, the hankering for leisure borders closely on a desire for not having to work, and though the protagonist wants to stop time to indulge in the present moment for ever and ever, his vision is in fact also nostalgic because he is trying to recuperate his life as a child and student. His nostalgia could be treated as temporal primitivism, a categorization of the simple life as an idyll that is nostalgic to the extent that this life cannot in fact be perpetuated; Agastya has to return to his job.

He shuffled in his chair. "I don't want challenges or responsibility or anything, all I want is to be happy-." He stopped, embarrassed. It seemed an awful thing to say. In that mild autumn sunlight [in Delhi] Madna seemed light years away, yet he knew that it would return, perhaps after dark, or whenever he was alone. It seemed unreal, yet accessible, a sleepwalking eighteen hours away... . He wanted to say, look, I don't want heaven, or any of the other ephemerals, the power or the glory, I just want this, this moment, this sunlight, the car in the garage, that music system in my room. These gross material things, I could make these last for ever... . This narrow placid world, here and now, is enough, where success means watching the rajnigandhas you planted bloom. I am not ambitious for ecstasy, you will ask me to think of

71 Gupta, A Sin of Colour, 93.

72 Gupta, A Sin of Colour, 122.

73 Gupta, $A$ Sin of Colour, 123.

74 Gupta, A Sin of Colour, 127.

75 See Anis Shivani's condemnation of Chaudhuri's texts in "Indo-Anglian Fiction: The New Orientalism," Race \& Class (New Delhi, Thousand Oaks, London: Sage Publications, 2006). A positive appreciation of Chaudhuri's notion of uselessness and his depiction of flânerie is provided by Saikat Majumdar in "Dallying with Dailiness: Amit Chaudhuri's Flâneur Fictions," Studies in the Novel 39.4 (2007): 448-64. 
the future, but the decade to come pales before this second, the span of my life is less important than its quality. I want to sit here in the mild sun and try and not think, try and escape the iniquity of the restlessness of my mind. Do you understand. Doesn't anyone understand the absence of ambition, or the simplicity of it. ${ }^{76}$

Agastya here fuses the moment in his uncle's house in Delhi-in which he is at rest in idyllic surroundings (see the bolded passages in the quotation) - with a life of stagnation and pleasurable indolence. He explicitly rejects the challenges of life, the expectations others have of him; he even repudiates any spiritual or philosophical uses of quietudeheaven or epiphany, ecstasy or worry about the future (highlighted in italics above). On the one hand, he savors the natural scene (sunlight, flowers); on the other hand, and this may be an ironic touch on the part of the author, he enjoys his freedom only in considerable middle-class comfort-a house, a car, and a stereo set are necessary to him. His insistence on simplicity and on the desire to dwell in the moment can therefore be interpreted as regressive and plainly unrealistic-neither car nor music system have come his way through his own efforts (nor are ever likely to).

This returns me to the depiction of otium in the contemporary Anglophone Indian novel. How would one characterize and terminologically classify the phenomenon of nostalgic investment in an allegedly native past of cultured otium within a framework of postcolonial theory?

We have seen that the equation of cultured leisure with an Indian tradition of otium as proposed by Sahgal or in contemporary texts by Anglophone South Asian authors is problematic for several reasons. On the one hand, there does not seem to be a continuous tradition of a concept or practice of otiose leisure that one could point to because there is a huge gap between the courtly traditions of cultured otium on the one hand and $\bar{a} d d \bar{a}$ and related concepts in contemporary northern India. ${ }^{77}$ Though a similarity exists between court cultures as represented in the epics and the Mughal and nawab courts of the sixteenth century onward, that similarity is superficial because the practice of the arts at pre-common era courts (the Sanskrit epics) remains too unspecific to be fruitfully compared with, say, the Mughal courts, about which we have extensive historical sources. And the evidence we have is, if at all, about practices but not about the experience of otium, though one may extrapolate on the basis of universally existing forms of courtly culture.

In addition, as I have observed, the Western/British discourse about leisure from the eighteenth century onward seems to be significantly determined by the colonial mimicry of native court culture and leisured ease, as well as by the Western denigration of the lower-class work ethic in conjunction with an imitation of vernacular upper-class leisured lifestyles. What also has to be considered is the rise of the Bengali (upper) middle class of entrepreneurs, advocates, and scholars, some but not all of them rajas

76 Chatterjee, English, August, 148. All emphases are mine.

77 See Chakrabarty, "Adda"; Johanna Hahn, "From Lonely to Loony Flâneur? The saṛaklmāp in Contemporary Hindi Literature (1950s onwards)," Zeitschrift für Indologie und Südasienstudien 31 (2014): 1-26. Related terms in Bangla are abashor and abakash. In Urdu the terms fursat and mauhlat can be mentioned. There is also chhutti in Urdu and Chhooti in Bangla, a lexeme used extensively by Tagore in his short stories. Thanks go to Farha Noor, who is part of the research project on contemporary Indian leisure that I direct. See http://www.sfb1015.uni-freiburg.de/en/subprojects/g-boundaries\#g4. 
(like Rammohan Roy) or from the local zamindar class, and prevalently Brahmins and kshatriyas. This class rose to social prominence and tried to wed Western reformist ideas to Indian traditions (the creation of the Brahmo Samaj). ${ }^{78}$ The leisured otium of these representatives of the upper (middle) classes could be regarded as a social innovation; it also has to be characterized as a hybrid constellation of Western (colonial) opportunities (social, political, financial) married to indigenous privilege. The artistic practices of members of this group can likewise be considered representative of hybridity because they combine religious traditions, genres of art practiced at the native courts with Western aesthetic influences, not least through the adoption of the English language and familiarization with European philosophic and artistic traditions. I therefore hold it to be highly problematic to label the leisure practices of the Bengali Renaissance "indigenous Indian leisure."

Finally, as initial results of our research project suggest, the idealization of "native otium" seems to be largely restricted to English-language texts, whether from South Asia or the diaspora, whereas novels in Urdu and Bangla appear to privilege leisure in constellations of social exchange and flânerie-motifs that are not the primary elements in the English-language depictions of leisure. There, art and nature as well as contemplative practices (but not asceticism, or only rarely so) figure prominently, though chatting, strolling through town, and shirking work also occur in some texts. In Chaudhuri's work, however, flânerie is a key structural aspect of his texts.

Under these circumstances, an analysis of otiose leisure in English-language fiction could be linked to the paradigms of postcolonial studies. One basic description of what these novels do when they idealize native leisure practices could be in terms of auto- and heterostereotypes. ${ }^{79}$ As I have suggested, the indigenous leisure showcased nostalgically in these texts might be characterized as the assumption, or adoption, of a Western (positive) heterostereotype about India by Indians themselves; therefore, we could posit the conversion of a cliché of latent Orientalism according to Edward Said, ${ }^{80}$ that of exotic (courtly) leisure, into an autostereotype.

From that perspective, the idealization of indigenous leisure, especially when contrasted with Western modes of work affording no real leisure, lends itself to a set of newer concepts that have been discussed in postcolonial theory since 2000. Foremost among these concepts is that of the postcolonial exotic. ${ }^{81}$ Huggan critiques the marketing of exotic India as a commercial strategy that caters to Western demands for escapist fantasy and often results in a resuscitation of colonial stereotypes and motifs linked to the Raj and the colonial novel. In analogy with the postcolonial exotic, the nostalgia for former leisure in the contemporary Anglophone novel could therefore be conceived of as

78 The Brahmo Samaj was the constitutive movement of the Bengali Renaissance and consisted in a secularization of Brahmanic traditions.

79 Hans Henning Hahn, ed., Historische Stereotypenforschung: Methodische Überlegungen und empirische Befunde, Oldenburger Schriften zur Geschichtswissenschaft, 2 (Oldenburg: BIS, 1995); Hans Henning Hahn, ed., Stereotyp. Identität und Geschichte (Frankfurt: Lang, 2002); Joep Leerssen, ed., Imagology: The Cultural Construction and Literary Representation of National Characters: A Critical Survey, Studia Imagolica: Amsterdam Studies on Cultural Identity, 13 (Amsterdam: Rodopi, 2007).

80 Edward W. Said, Orientalism: Western Conceptions of the Orient ([1978]; reprint, London: Penguin, 1995).

81 Graham Huggan, The Postcolonial Exotic: Marketing the Margins (London: Routledge, 2001). 
an expression of autoexoticism, a concept recently put on the map in a special issue of PMLA. ${ }^{82}$ It should, however, be noted that the otium novels discussed in our project fall outside the group of internationally acclaimed high-profile work that has been boosted in the wake of Booker prizes.

In her introduction to the set of articles she edited, Li defines autoexoticism as follows:

[t]he agent of exoticist construction and its recipient are reversed in autoexoticism-from the weak to the powerful, the marginalized to the dominant. This self-reflexivity of autoexoticism thus reveals the fascinating and intriguing distance between the self and the self, for we realize that the self, like culture, is multiple and created through diverse discourses, and that self-perception originates from others' perception of oneself. $^{83}$

The term originally derives from Marta Savigliano's book Tango and the Political Economy of Passion (1995), ${ }^{84}$ in which Savigliano characterizes the concept as "the condition, common to musicians in many parts of the world today, of being able to produce a marketable art only by exoticizing oneself and one's culture." 85

For Huggan and Li, exoticism is "tainted with negativity" and has "immediate connotations of unethical appropriation and superficial engagement with the other." 86 However, some of the articles collected by Li for that March 2017 issue of PMLA in fact illustrate processes that go beyond sheer marketability and describe situations that are actually the inverse of the schema delineated by Huggan. For instance, the essay by Fukuzawa illustrates the adoption of Lafcadio Hearn's collection of Japanese folktales by the Japanese in the form of the book Kwai-Dan. ${ }^{87}$ Now, although Hearn's publication of Japanese folk stories was a commercially successful venture, it was undertaken in the spirit of cultural translation and-due to the fact that Japan was not a colony-not representative of a colonial exotic, though Orientalist to the extent of rendering the culture of Japan exotic and fantastic. Secondly, and more importantly, the later adoption by the Japanese school system of Kwai-Dan as a set text in their educational curriculum cannot be said to be motivated by commercial concerns at all, though it clearly betokens a nostalgia for a lost indigenous tradition of folklore. This kind of autoexoticism is therefore neither postcolonial nor is it a kind of self-marketing under the aegis of global capitalism. In other words, the adoption of latently Orientalist stereotypes by the culture about which they have been generated can simply be motivated by the loss of indigenous

82 See Li, "Introduction: From the Exotic to the Autoexotic."

83 Li, "Introduction: From the Exotic to the Autoexotic," 393-94.

84 Marta Savigliano, Tango and the Political Economy of Passion (London: Westview Press, 1995).

85 Li, "Introduction: From the Exotic to the Autoexotic," 392; quoting James Parakilas, "How Spain Got a Soul," in The Exotic in Western Music, ed. Jonathan Bellman (Boston: Northeastern University Press, 1998), 137-93.

86 Li, "Introduction: From the Exotic to the Autoexotic," 392.

87 Naomi Charlotte Fukuzawa, "Autoexotic Literary Encounters between Meiji Japan and the West: Soseki Natsume's The Tower of London (1905) and Lafcadio Hearn's Kwaidan (1904),” PMLA 132.2 (2017): 447-54. 
traditions and their recuperation on the basis of the only available material, which happens to be that produced by Western scholars or cultural ambassadors. ${ }^{88}$

My suggestion for a term to characterize the phenomenon of nostalgic leisure is to recur to the concept of Occidentalism. ${ }^{89}$ In analogy to Said, I would posit the existence of both manifest and latent Occidentalism. Buruma and Margalit's Occidentalism, for instance, exclusively focuses on negative stereotypes about the West. However, positive stereotypes have always existed as well as fantasies about the West. Compare the following passage from Sunetra Gupta's The Glassblower's Breath:

Turning for a last farewell glance, he [Avishek] had been hit by the pastry texture of the snow-dusted spires, and this gentle vision had resurrected his desire to craft in cake flesh the spires of Oxford, his first dream, his last dream, his one enduring fantasy, Balliol in bakemeat, a gingerbread Christchurch. ${ }^{90}$

Like Niharika's idealization of Tintern Abbey, this is an exotically heightened vision of Oxford. Chaudhuri's depiction of London in Odysseus Abroad displays a comparable fascination with England. ${ }^{9}$

As regards otiose leisure, one therefore wonders whether the phenomenon I have been describing - the nostalgic representation of leisure-could not consist in a kind of latent re-occidentalization, or (to put it differently) in the adoption of a positively evaluated tradition of the West-its criticism of capitalism by means of the praise of leisure-now reapplied to India. The phenomenon would therefore combine influences from both South Asian predilections for nostalgia with a literary depiction of otium or leisure that accidentally harkens back to traditions of the praise of idleness in British literature. $^{92}$ Such a proposal also has to acknowledge that clear-cut dichotomies of colonialism and postcolonialism do not sufficiently manage to do justice to the complex imbrications of self and other, present versus past, and enthusiastic adoption versus detraction that characterize the hybridized scenarios of literary nostalgias of leisure in Anglophone South Asian fiction.

88 One does, however, have to acknowledge that Hearn's work of recuperation was performed during a period in Japan when Western influences had been adopted in the Meiji era, deliberately sidelining indigenous folk culture as unenlightened and to be superseded by (Western) rationality. Thus, Japan in fact experienced a similar influx of Western ideas and resulting processes of mimicry as did India, without literally being a colony.

89 On Occidentalism see Meltem Ahiska, "Occidentalism: The Historical Fantasy of the Modern," The South Atlantic Quarterly 102.2-3 (2003): 351-79; Ian Buruma and Avishai Margalit, Occidentalism: The West in the Eyes of Its Enemies (New York: Penguin, 2004); and James G. Carrier, ed., Occidentalism: Images of the West ([1995]; reprint, Oxford: Oxford University Press, 1996).

90 Sunetra Gupta, The Glassblower's Breath ([1993]; reprint London: Penguin, 1994).

91 Amit Chaudhuri, Odysseus Abroad (New York: Knopf, 2015).

92 Fludernik and Nandi, Idleness, Indolence and Leisure Leisure in British Literature. 